中山間地域における地域外家族による農作業の労働力の特徵と意義

～長野市信更地区赤田区を事例として〜

\title{
FEATURE AND MEANING OF PARTICIPATION IN AGRICULTURAL LABOR IN HIGHLAND BY NON-RESIDENT MEMBERS OF RESIDENT FAMILY \\ $\sim$ In the case of Akada-ku in Shinko-chiku, Nagano-city
}

細田祥子*, 後藤春彦**, 山崎義 人***

Shoko HOSODA, Haruhiko GOTO and Yoshito YAMAZAKI

\begin{abstract}
The purpose of this study over labor forces by non-resident members of farmers is first to identify their feature in each life stages of farmers and then to clarify their parts in farming in highland area.The followings became clear.

1)Roles which resident and non-resident members play in agricultural/works changes upon their life stages.

2)Non-resident members provides labor force corresponding to their life stages for farminghouse with needs of labor according to their life stage. 3)Such complementary act has a prolonged structure corresponding to life cycle of each family.

The family style shown in this paper will be more important in highland area as farming families ages.And the style itself will be diversified as lifestyle of each non-resident individual changes.

Necessity of recognizing the viewpoint including not only the farmhouse alone but non-resident family members is suggested to support agriculture in highland area.
\end{abstract}

Keywords : cultivation abandonment, non-resident family members, age classification,

agricultural work, labor force, average of days

耕作放棄、地域外家族、年齢分類、農作業、労働力、平均日数

1 章.はじめに

\section{1-1. 研究の背景}

日本において、終戦直後ではおよそ $3: 7$ であった都市 : 農村人口 比が、21 世紀を迎えた現在、およそ $8: 2$ に達した ${ }^{1)}$ 。さらに高跲化 率は世界のトップレベルに達している。これら、定住型社会からの 激しい人口流動と急速な高齢化などの現象は、都市、農村を問わず、 地域社会における様々な問題の一因であると考えられ、都市と農村 の連携の中に問題を解く鍵を見いだす必要があると考える。その上 で、本研究では農村における問題を扱う。

中山間地域の農村では、終戦から現在にかけての過疎・高齢化の 進行や兼業化に伴い、耕作放棄が著しく、農業に関する不安はます ます大きくなっている。つまり中山間地域においては、地域内の労 働力の低下が起きている。

また、社会背景の変化に応じて家族像も変容を遂げた。農業は以 前「イエ」という家族を単位として行われていたが、都市と農村へ の広域的な、家族の分散が起きたのである。しかし、農村を離れた 家族は帰省を兼ねて農作業の手伝いを行うなど、中山間地域で活動 を行っており、これを「緩やかなイエ」としてつながりを保つ家族 像として新しく捉えなおす必要があるのではないだろうか。 1-2. 研究の目的
中山間地域の生活を支える農業に着目すると、現代の農家の就業 構造の多様化により、農家のライフステージによってその労働力が 変化すると考えられる。これに伴い、農家の各ライフステージに対 応した形で、地域外に住む家族の労働力が、農家の低下した労働力 を補い、中山間地域での農業を支え得る可能性があると考えられる。

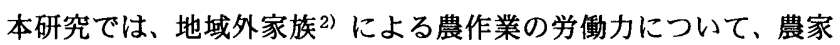
の年跲分類ごとの特徵を明らかにすることを目的とし、さらに、中 山間地域の農業における意義を述べる。

\section{1-3. 研究の位置づけ}

家族に関する研究は社会学の分野で広く行われているが、建築学 の分野では、様々な地域を対象とし、離れて住む家族のネットワー クという観点から、居住・住環境を考える必要性が論じられている 3)。本研究も、離れて住む家族に注目する同様の視点をもつが、居住 問題ではなく農村における農作業に焦点を当てている。一方、農業 経済学の分野では、離れて住む家族の労働力に関して、その後継ぎ としての可能性に焦点を当てた調査 $\left.{ }^{4}\right)$ がなされている。本研究は、農 業における将来の後継問題ではなく、現時点での家族の農作業への 参加に注目している。また、建築学・農村計画の分野における農作 業に関する研究は、農家個別の管理作業に焦点を当て農地の空間的 特徴や農家の属性との関連を明らかにしたものがある5)。しかし、い
* 株地域総合計画研究所 工修

** 早稻田大学理工学部 教授・工博

*** 早稲田大学理工学総合研究センター 助手・工修
Comprehensive \& Regional Planning, Inc., M. Eng.

Prof., Waseda University, Dept. of Architecture, Dr. Eng.

Assoc., Advanced Institute for Sci. and Eng., Waseda Univ., M. Eng 
ずれも空間管理の主体は農村の居住者に限られている。

本研究は、中山間地域の耕作放棄の防止に向けて、離れて住む家 族による農作業の労働力の実態を明らかにし、その意義を評価・支 援する視点を得るための基礎的な研究に位置づけられる。

\section{1-4. 分析の枠組みと方法}

本研究で用いる用語の定義を表 1.に示す。長野市信更地区赤田区 を対象地とし、農家と地域外家族 のライフステージを考慮に入れた 年齢分類を行ない、それぞれが対 象地で行う農作業 ${ }^{6)}$ の労働力と 平均日数について取り上げる。な お、農家の年路分類間の比較を行

\section{表 1.用語の定咅}

\begin{tabular}{|c|c|}
\hline 地域外家藏 & 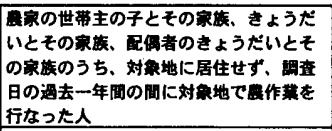 \\
\hline 労的力 & 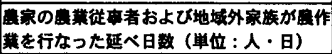 \\
\hline 平均日数 & 一人当たりの労觔力（單位：日） \\
\hline 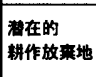 & 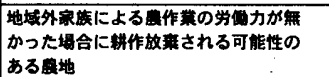 \\
\hline
\end{tabular}

うために、農地 1 ha を単位面積とし、単位面積当たりの農作業の労 働力と平均日数を扱う。また、対象地の主な農地は水田とりんごの 果樹園である。機械化の進んでいる水田と、主な作業を手作業で行 う果樹園とについてそれぞれ分析を進める。

農家と地域外家族についてライフステージを考慮に入れた年秢分 類を行なう (2 章)。次に、農家と地域外家族の労働力および地域外 家族の年齢分類ごとの労働力から、農家の年齢分類ごとにみた労働 力の特徵をみていく (3 章)。また、地域外家族による農作業の量と 質に対する農家の満足度に関する調査から、地域外家族による労働 力の評価を農家の年齢分類ごとに示す (4 章)。さらに、地域外家族 による農作業が無い場合を仮定した質問による調査から、地域外家 族の、労働支援主体7) としての必要性、および耕作を続ける上での 必要性を明らかにする (5 章)。以上をふまえ、農家の各年齢分類に おける地域外家族の労働力の特徵を示し、その意義を述べる (6章)。

\section{2 章.農家と地域外家族の年羚分類}

本章では、調査で得られた農家と地域外家族をそれぞれ年齢に よって分類し、それぞれの年軨分類での農家と地域外家族の関係を 示す。調查の概要を表 2. に示す。

\section{表 2. 鲷查の概要}

\begin{tabular}{|c|c|c|}
\hline & 閏要。 & 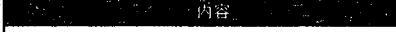 \\
\hline 奶魚者 & 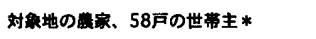 & \multirow{2}{*}{ 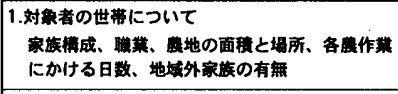 } \\
\hline \multirow[t]{2}{*}{ 略查方法 } & \multirow{2}{*}{ 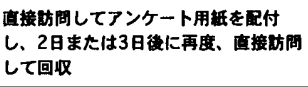 } & \\
\hline & & \multirow{2}{*}{ 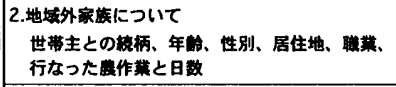 } \\
\hline 西付期閏 & 2002年10月2日 3日 & \\
\hline 回收期間 & 2002年10月4日 6日 & \multirow{2}{*}{ 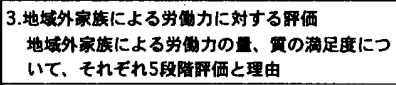 } \\
\hline 回收数 & $54(93.1 \%)$ & \\
\hline 有奻回管数 & $51(87.9 \%)$ & 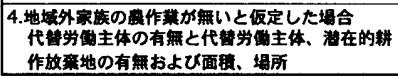 \\
\hline
\end{tabular}

\section{2-1. 農家の年齢分類}

\section{2-1-1. 地域外家族の有無}

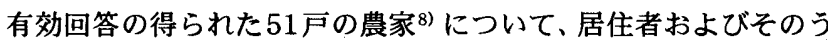
5の農業従事者の年跲別人口を図1.に示す。居住者の人口は 187 人 （男 : 女 $=93: 94 ） 、$ 農業従事者の人口は 90 人（男 : 女 $=40: 50 ）$ であった。

農業従事者についてみると、男性は 50 歳代以上、女性は 30 歳代 後半以上である。また、男性は 60 歳代から、女性は 50 歳代が大半

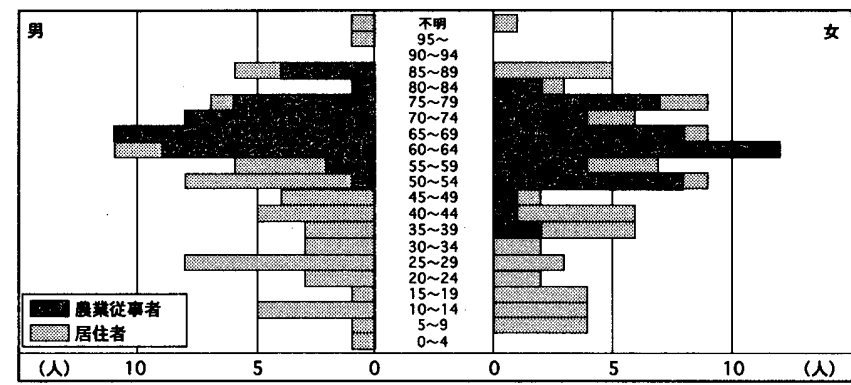

图 1. 年齢別人口

を占め、その年代のほぼ全員が農業従事者であることが分かる。女 性は男性より若い世代が農業に関わっている。

地域外家族の有無別の農家の特徵を表 3.に示す。 51 戸中 31 戸の 農家に地域外家族がいる。いない農家の方が 1 戸当たり農業従事者 数が若干多く、農業従事者の平均年跲も若干若い。また、農業従事 者数が 1 人の農家の約 7 割に地域外家族がいることがわかる。

表 3. 地域外家族の有無別の農家の特徽

\begin{tabular}{|c|c|c|c|c|c|c|c|c|c|c|c|c|}
\hline & \multirow{2}{*}{ 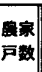 } & \multicolumn{3}{|c|}{ 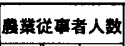 } & \multirow{2}{*}{ 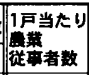 } & \multirow{2}{*}{ 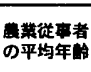 } & \multicolumn{4}{|c|}{ 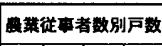 } & \multicolumn{2}{|c|}{ 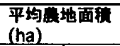 } \\
\hline & & 合lt & 男 & 女 & & & 11 & $2 \lambda$ & 3 人 & $4 \lambda$ & 水田 & 果澍國 \\
\hline & 31 & 53 & 25 & 28 & 1.71 & & 13 & 15 & 2 & 1 & 0.26 & 0.52 \\
\hline orat & 20 & 37 & 15 & 22 & 1.85 & 64.9 & 5 & 13 & 2 & 0 & 0.20 & 0.54 \\
\hline
\end{tabular}

\section{2-1-2. 農家の年齢分類ごとの特往}

以下では、地域外家族のいる31戸の農家を対象として分析をすす める。農家を各戸ごとの農業従事者の平均年秢によって、「若年農 家」「中年農家」、「高年農家」の 3 つに分類した。農家の年齢分類 の方法を図 2.に示す。

年齢分類による農地面積の内訳を図 3. に示す。水田、果樹園とも 中年農家の農地が大半を占める。

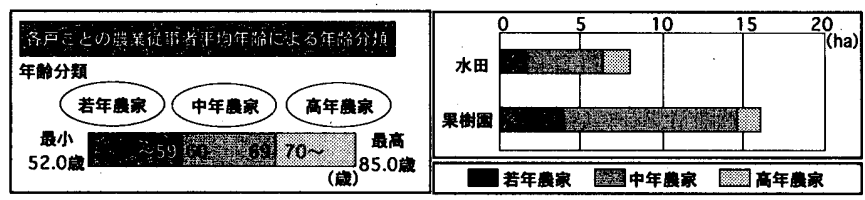

図 2. 農家の年齢分類の方法

图 3. 農地面積の内訳

年齢分類ごとの農家の特徵を表4.に示す。若年農家は女性が多く、 農業従事者数 1 人の農家が多い。中年農家は男女はほほ半々で農業 従事者数は 2 人の農家がほとんどであり、1戸当たりの農業従事者数 が最も多い。平均農地面積は水田、果樹園ともに 3 年椧分類中最も 大きい。高年農家は男性が多く、農業従事者数は 1 人の農家が多い。 また、 1 戸当たりの農業従事者数が最も少ない。平均農地面積は水 田、果樹園ともに 3 年齢分類中最も小さい。

表 4. 年齢分類ことの農家の特徽

\begin{tabular}{|c|c|c|c|c|c|c|c|c|c|c|c|}
\hline & \multirow{2}{*}{$\begin{array}{l}\text { 貲家 } \\
\text { 芦数 }\end{array}$} & \multicolumn{3}{|c|}{ 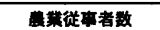 } & \multicolumn{4}{|c|}{ 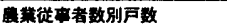 } & \multirow{2}{*}{$\begin{array}{l}\text { 1戸当たり } \\
\text { 光莱煺事者数 }\end{array}$} & \multicolumn{2}{|c|}{ 平均軹地面䅡(ha) } \\
\hline & & 合时 & 男 & 女 & 11 & $2 \lambda$ & $3 \hat{\lambda}$ & $4 \lambda$ & & 水田 & 果術圆 \\
\hline 若年禹家 & 7 & 10 & 3 & 7 & 5 & 1 & 1 & 0 & 1.4 & 0.23 & 0.57 \\
\hline 中年簬家 & 15 & 31 & 14 & 17 & 2 & 11 & 1 & 1 & 2.1 & 0.31 & 0.71 \\
\hline 高年昔家 & 9 & 12 & 8 & 4 & 6 & 3 & 0 & 0 & 1.3 & 0.19 & 0.17 \\
\hline
\end{tabular}

\section{2-2. 地域外家族の年齢分類}

\section{2-2-1. 地域外家族の年路分類}

31 戸の農家から地域外家族 74 人についての回答が得られ、72人

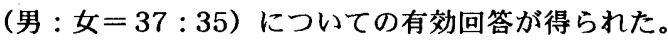

地域外家族の年齢別人口を図 4 . に示す。男性では 30 歳代後半が 


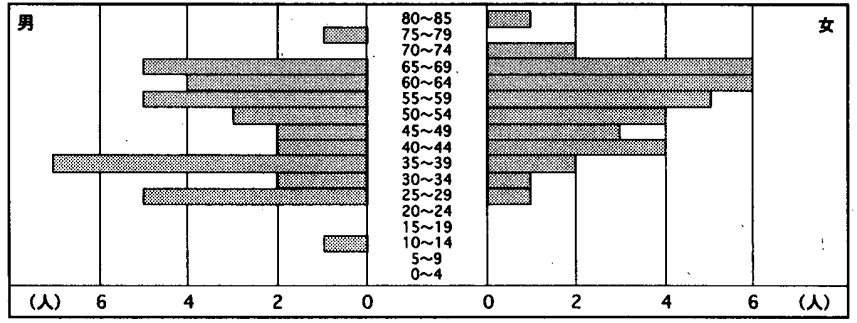

图 4. 地域外家族の年数別人口

最も多く、40〜 50 歳代前半でいったん減るものの 50 歳代後半から 60 歳代にかけて增える。また、20歳代後半も多い。女性では 60 歳 代が最も多い。男性に比べて 30 歳代以下が少ない。

地域外家族を年舲によって 4 つに分類した ${ }^{9)}$ 。50 歳未満の「青年 家族」には、10 歳代から 40 歳代の地域外家族が含まれるが、これ らは皆農家の子とその家族であり、子育てと仕事の両方を抱える年 代であることから同じ年齢分類とした。 50 歳以上 60 歳未満の「若 年家族」は、子育ては終わったが定年退職前という年代である。 60 歳以上 70 歳未満の「中年家族」 は、定年退職を迎えた年代であ る。また 70 歳以上を「高年家族」 とした。地域外家族の年略分類の 方法を図 5. に示す。

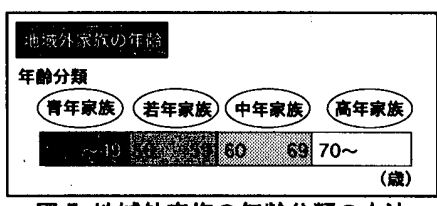

図 5. 地域外家族の年齢分類の方法
また地域外家族の職業は大き

く、「勤め」「農業」「無職」の 3 つに分類でき、その他、学生や自営 業なども見られた。

\section{2-2-2. 農家の年齢分類ごとにみた地域外家族の特徽}

農家の年路分類ごとに、地域外家族の年齢分類ごとの農家との続 柄や瞕業、居住地を表 5.に示す。

若年農家には妻の姉妹で主婦などの無職である中年家族が最も多 く、次いで子である青年家族が多い。中年農家には青年家族が最も 多く、全員が子とその家族で勤めが多い。また、他の年齢分類の農 家の地域外家族に比べ、職業に農業が多く、居住地に市内が多いこ とが特徵である。高年農家にも青年家族が最も多く、全員が子とそ の家族であり、勤めと無職が同数ずついる。次いで、若年家族、中 年家族が同数ずつ続く。また、居住地に市外が多いのが特徽である。

\section{2-3. 農家と地域外家族の関係}

以上の傾向から読みとれる、農家と地域外家族の関係を図 6. に示

表 5. 農家の年齢分類ことの地域外家族の特挍

\begin{tabular}{|c|c|c|c|c|c|c|c|c|c|c|c|c|c|c|}
\hline & & \multicolumn{3}{|c|}{ 人数 } & \multicolumn{3}{|c|}{ 栖* } & \multicolumn{4}{|c|}{ 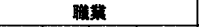 } & \multicolumn{2}{|c|}{ 居住地 } & \multirow{2}{*}{$\begin{array}{l}\text { 1戸当たり } \\
\text { の人数 }\end{array}$} \\
\hline & & 合豇 & 男 & 女 & 子 & 夫 & 裹 & 䘄め & 覃 & \begin{tabular}{|l|l|l} 
碚 \\
\end{tabular} & その他 & 市内 & 市外 & \\
\hline \multirow{5}{*}{ 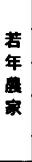 } & 骨年家族 & W & 3 & 2 & (2) & - & 1 & 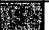 & - & - & - & 2 & 3 & 0.71 \\
\hline & 君年家族 & 2 & 0 & 2 & - & 1 & 1 & 1 & - & - & 1 & 2 & - & 0.29 \\
\hline & 中年家站 & $x_{1}$ & 2 & 领 & - & 1 【1] & 10 & - & 1. & 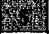 & - & 3 & 3 & 0.86 \\
\hline & |高年家康 & 1 & 0 & 1 & - & 1 (1) & - & - & - & 1 & - & 1 & - & 0.14 \\
\hline & 合部 & 14 & 5 & 9 & 4 & 3 & 7 & 6 & 1 & 6 & 1 & 8 & 6 & 2.00 \\
\hline \multirow{5}{*}{$\begin{array}{c}\text { 中 } \\
\text { 年 } \\
\text { 露 }\end{array}$} & 青年家薂 & 7 & (1) & 7 & (6) & - & - & 6 & - & 2 & 4 & 4 & 6 & 1.20 \\
\hline & 若年家族 & 4 & 5 & 5 & - & 8 & 2 & $x$ & 1 & 2 & 2 & 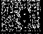 & 2 & 0.67 \\
\hline & 中年家疾 & 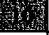 & 4 & 6 & 2 (2) & ton & 2 [1] & - & 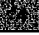 & 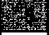 & 1 & (1) & 3 & 0.67 \\
\hline & 高年家族 & 3 & 1 & 2 & - & 3 & - & - & 2 & - & 1 & 3 & - & 0.20 \\
\hline & 合部 & 41 & 21 & 20 & 20 & 14 & 7 & 17 & 7 & 9 & 8 & 30 & 11 & 2.73 \\
\hline \multirow{4}{*}{$\begin{array}{l}\text { 离 } \\
\text { 年 } \\
\text { 晋 } \\
\text { 家 }\end{array}$} & 青年家算 & 跑 & 5 & 2 & 10 & - & - & Sy & - & ; & 1 & - & 14 & 0.78 \\
\hline & 若年家洗 & W & 3 & 2 & 14 & - & - & 型的 & - & - & 1 & 2 & m & 0.56 \\
\hline & 中年家薮 & X & 3 & 2 & $1[1]$ & - & the & - & - & 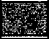 & - & - & 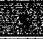 & 0.56 \\
\hline & 合晫 & 17 & 11 & 6 & 13 & - & 4 & 7 & - & 8 & 2 & 2 & 15 & 1.89 \\
\hline
\end{tabular}

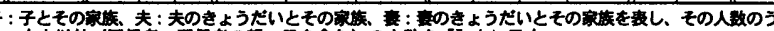

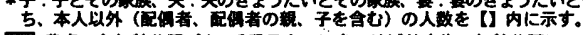

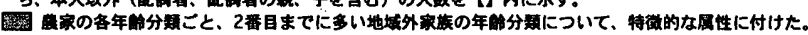

し、年秢分類を追ってみていく。

若年農家は、妻が一人で農業を行っていることが多い。そのため 地域外家族には中年家族である妻のきょうだい、特に姉妹が多い。 中年農家では夫婦で農業を行っていることが多い。そのため地域外 家族には夫または妻のきょうだいとその家族が多い。高年農家では 夫が一人で農業を行っていることが多いが、地域外家族には妻の きょうだいが多い。

このように、地域外家族は、農家の農業従事者と血縁的に近しい 場合が多いことがわかる。

なお、どの年齢分類でも、農家の子である青年家族は比較的多い。 特に中年農家と高年農家の地域外家族には農家の孫も含まれており、 次の世代も農作業を行っている。

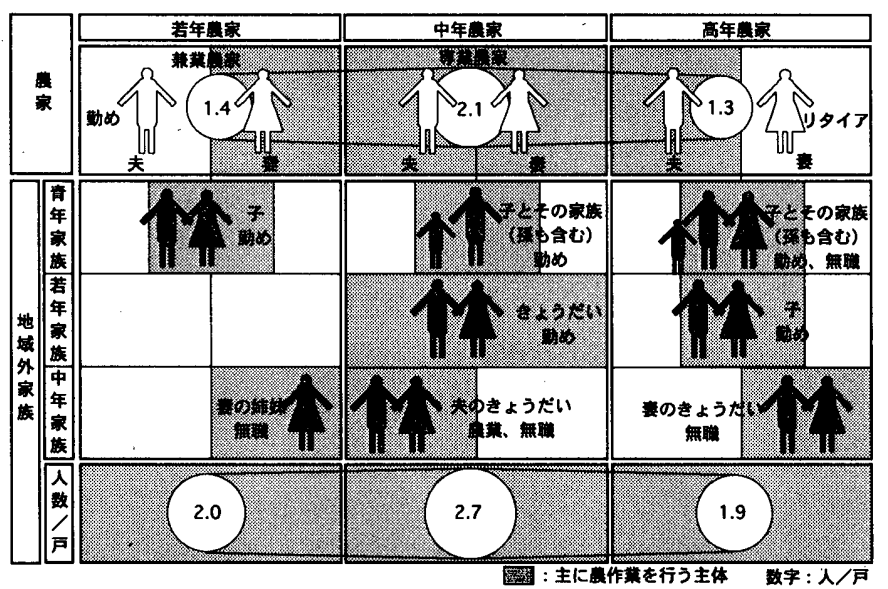

図 6. 農家と地域外家族の関係

\section{3 章 . 農家の年秢分類ことにみた労働力の特徽}

\section{3-1.農家と地域外家族の労働力}

ここでは農家および地域外家族の労働力の、農家の年跉分類によ る違いを明らかにする。

\section{3-1-1. 労働力の合計と地域外家族の労働力の割合}

水互と果樹園それぞれについて、一年間にかける単位面積当たり の労働力と地域外家族の労働力の割合を図 7.に示す。水田では、合 計をみると若年農家が少なく、中・高年農家に比べて $60 \%$ 程度であ る。地域外家族の労働力は、年橉分類間で大きな違いはない。果樹 園では、合計をみると年秢分類によってほとんど変わらないが、農 家の年齢が上がる程、地域外家族の労働力の割合が水田で低くなり、 果樹園で高くなることがわかる。

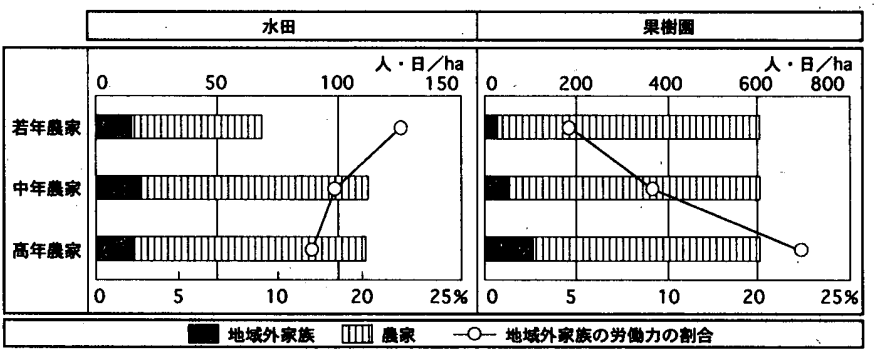

图 7.単位面矰当たりの労湖力と地域外家族の労能力の割合

\section{3-1-2. 平均日数}

単位面積当たりの平均日数を図8.に示し、年齢分類間の比較を通 して、それぞれの特徴を述べる。 
若年農家では、果樹園で農家の平均日数が最も長いことが特徽的 である。中年農家は、水田、果樹園の両方で農家、地域外家族とも、 それぞれ最も短い。高年農家は、水田、果樹園の両方で農家の平均 日数が比較的長く、地域外家族の平均日数が果樹園で最も長いこと が特徵である。

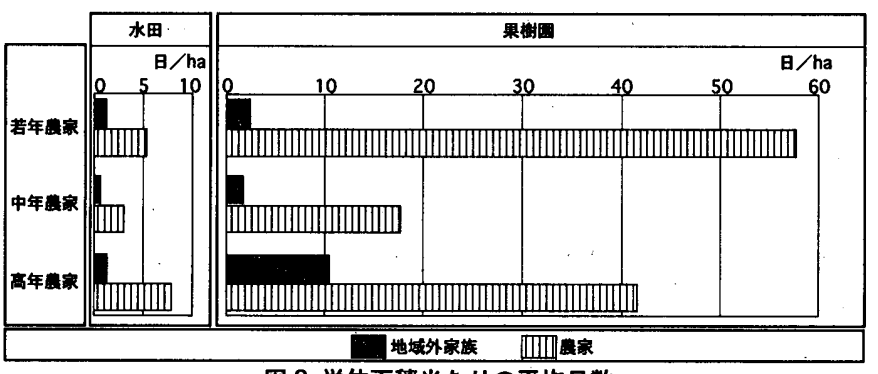

图 8. 単位面糟当たりの平均日数

\section{3-1-3. 作業内容別の労㨽力}

次に、作業内容別の労働力と地域外家族の労働力の割合を図 9. に 示す。どの年秢分類の農家も、水田では最も労働力のかかる「草刚 り」を農家がほとんどを行ない、短時間で終わらせる必要のある「刚 入れ」「脱豰」に地域外家族の労働力が集中する。果樹園では「摘花・ 摘果」「葉摘み・玉回し」「収穫」など労働力のかかる農作業に地域 外家族の労働力が集まっている。また、水田、果樹園ともに農家の 年路分類が上がる程、秋の収穫時期の農作業よりも春の農作業に労 働力をかけ、地域外家族の労働力の割合も高くなることがわかる。

若年農家では、水田で「草刈り」に次いで「刚入れ」「脱穀」に労 働力をかけ、地域外家族の労働力も高い。地域外家族の労働力の割 合は $60 \%$ 強である。果樹園では地域外家族は主に「摘花・摘果」「葉 摘み・玉回し」「収穫」を行なっている。

中年農家では、水田で「草刈り」に次いで「刈入れ」「脱穀」に労 働力をかける。地域外家族の労働力の割合は「刚入れ」「脱穀」では $30 \%$ 前後、また「田植え」では $15 \%$ 弱となる。果樹園では、地域外 家族の労働力の割合は若年農家に比べ高くなり、特に「摘花・摘果」 と「収穫」で $10 \%$ 強である。

高年農家では、水田で「草刈り」に次いで「田起こし」「農薬散布」 に労働力をかける。地域外家族の労働力は「田植え」で高く、労働 力の割合は $50 \%$ 弱と高い。果樹園で「剪定」「摘花・摘果」が高く

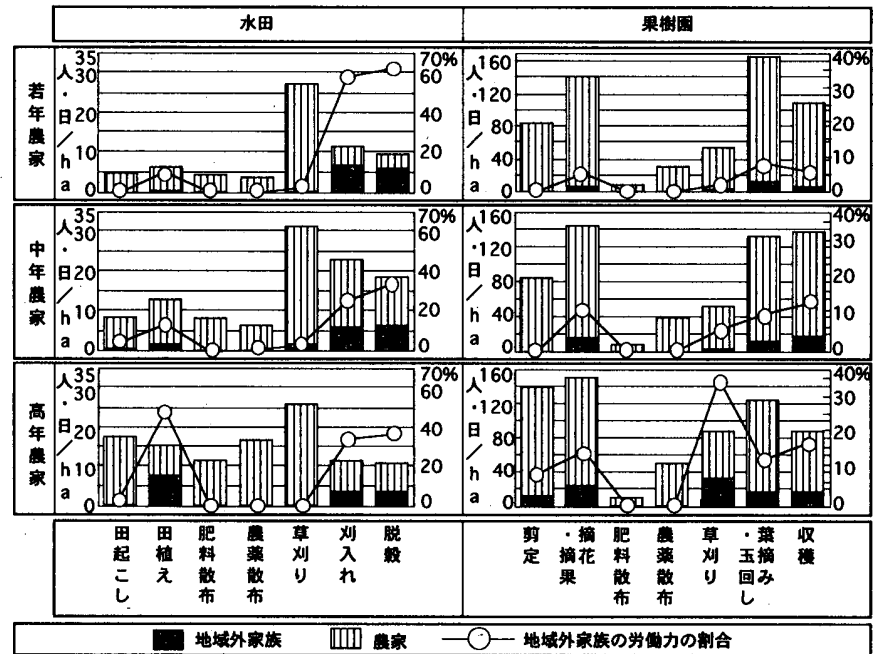

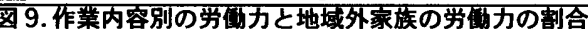

なる。地域外家族の労働力は「草刈り」が高く、労働力の比は $35 \%$ 強と高い。また高年農家の地域外家族のみが「剪定」を行なってお り、他の年㱓分類の農家に比べ、地域外家族が多くの作業内容を行 なっている。

\section{3-2. 地域外家族の年齢分類ことの労働力}

ここでは地域外家族の年齢分類による労働力の違いを農家の年龄 分類ごとに明らかにする。

\section{3-2-1. 労徽力の割合}

地域外家族の年粭分類ごとの労働力の割合を図 10. に示す。

どの年齢分類の農家も共通して若年家族と中年家族の労働力の割 合が水田より果樹園で高く、青年家族の労働力の割合が水田より果 樹園で低い。

若年農家では、水田、果樹園ともに中年家族の割合が高い。中年 農家では、水田、果樹園ともに青年家族の割合が高い。高年農家で は、水田は青年家族の割合が高く、果樹園では中年家族、次いで若 年家族の割合が高い。

\section{3-2-2. 平均日数と人数}

平均日数と人数を図 11. に示す。

若年農家では、若年家族と中年家族は水田より果樹園で平均日数 も人数も多い。中年農家では、高年家族を除くどの年舲分類の地域 外家族も、水田より果樹園で、平均日数も人数も多くなる。高年農 家では、青年家族は水田では人数が最も多いが平均日数は短く、果 樹園では水田より人数が減り平均日数が長くなる。若年家族と中年 家族は水田より果樹園で平均日数が極端に長くなる。

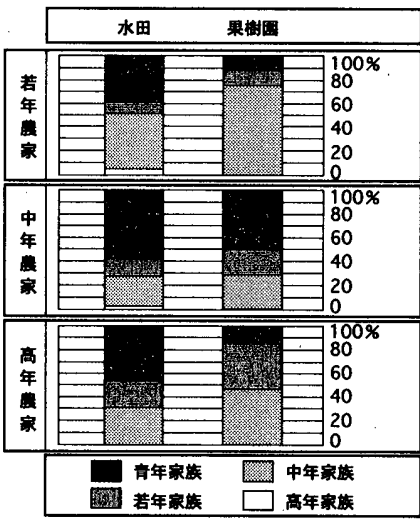

図 10. 労㑬力の割合

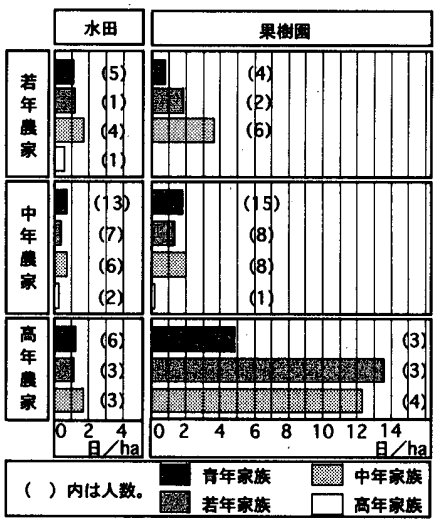

图 11. 人数と平均日数

\section{3-2-3. 作業内容別の労的力}

作業内容別の労働力を図 12. に示す。

若年農家では、地域外家族は水田で「刈入れ」「脱穀」を主に行な うが、内訳は中年家族、次いで青年家族が多い。果樹園では「摘花・ 摘果」「葉摘み・玉回し」のほとんどを中年家族が行っている。

中年農家では、水田で「田起こし」「田植え」「草刈り」を主に青 年家族が行い、「刚入れ」「脱穀」を青年家族を中心に各年粉分類の 地域外家族が行なう。果樹園で「草刈り」を青年家族のみが行い、「摘 花・摘果」「葉摘み・玉回し」「収穫」を青年家族を中心に各年齢分 類の地域外家族が行なう。

高年農家では、水田は「田植え」を中年家族と青年家族が行い、「刈 入れ」「脱穀」は若年家族と青年家族が行なう。果樹園は「剪定」「摘 花・摘果」「葉摘み・玉回し」「収穫」を主に中年家族が行ない、「草 


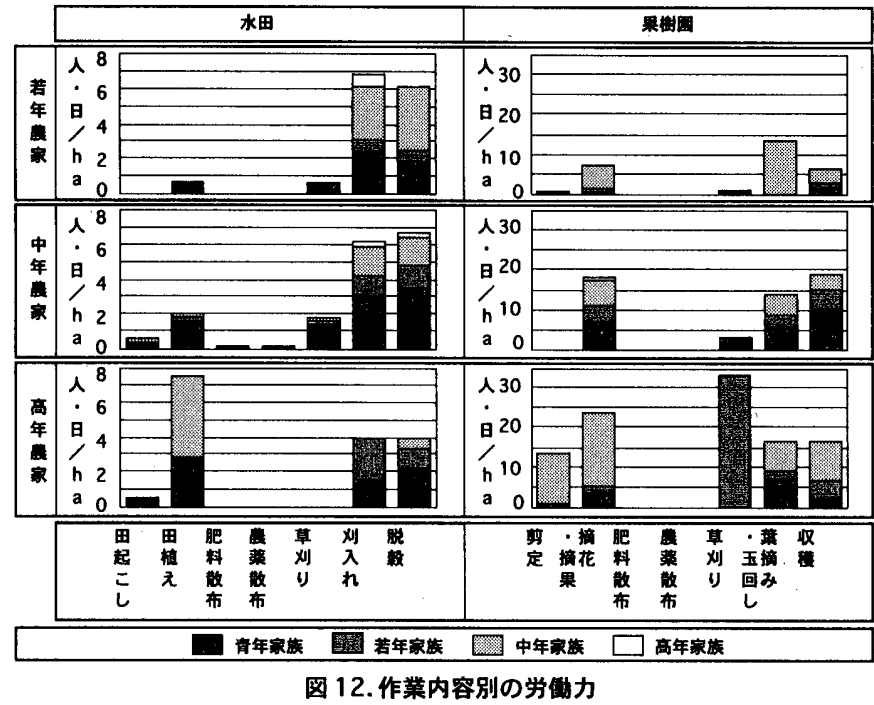

刈り」を若年家族が行なう。

\section{3-3. 小括}

以上から、単位面積当たりの労働力について、農家の年齢分類ご とに明らかになったことをまとめる。

若年農家では、水田にあまり労働力をかけず、そのうちの地域外 家族の労働力が占める割合が大きい。短時間で終わらせる必要のあ る収穫に、中年家族と青年家族の労働力が集まる。一方、果樹園で は、地域外家族の労働力はほとんどなく、農家の負担が大きいと言 える。

中年農家では、青年家族を中心に各年代の労働力が春と秋の農繁 期に集まることによって、労働力のかかる農作業も短時間で行うこ とができると言える。

高年農家では、水田では地域外家族が春の農作業に多く労働力を かけている。特に「田植え」では地域外家族の労働力が約半分を占 め、中年家族が比較的長時間かけて行なう。逆に、収穫時期の農作 業を若年家族と青年家族が短時間で行なう。果樹園では地域外家族 が行なう作業内容が多く、労働力の割合も大きい。特に若年家族と 中年家族が長時間かけて行なう。農家の体力が低下しており、農作 業が長時間になるが、それを補うため地域外家族がその年跲分類に よって役割分担を行なっていると考えられる。

\section{4 章.地域外家族の労働力に対する評価 4-1. 労㗢力の量について}

農家に、地域外家族の労偅力についてその量の満足度 ${ }^{10)}$ を 5 段階 で評価させた。量に対する満足度と理由を図 13. に示す。

どの年齢分類の農家も水田より果樹園で满足度が低い。

若年農家は水田、果樹園とも最も満足度が低く、特に果樹園では +0.1 と低い。水田では、満足（「非常に満足」か「どちらかという と満足」）の理由として、必要な時に労働力が得られること、不満 (「非常に不満」か「どちらかというと不満」) の理由として、人数の 不足が挙がった。果樹園では不満の理由として、日数が短く品質が 落ちるが、長時間頼みたくても地域外家族の都合を気にしているこ となどが多く挙がった。

中年農家は水田、果樹園とも同程度の満足度を示し、比較的高い。 満足の理由として必要な時に労㗢力が得られること、不満の理由と

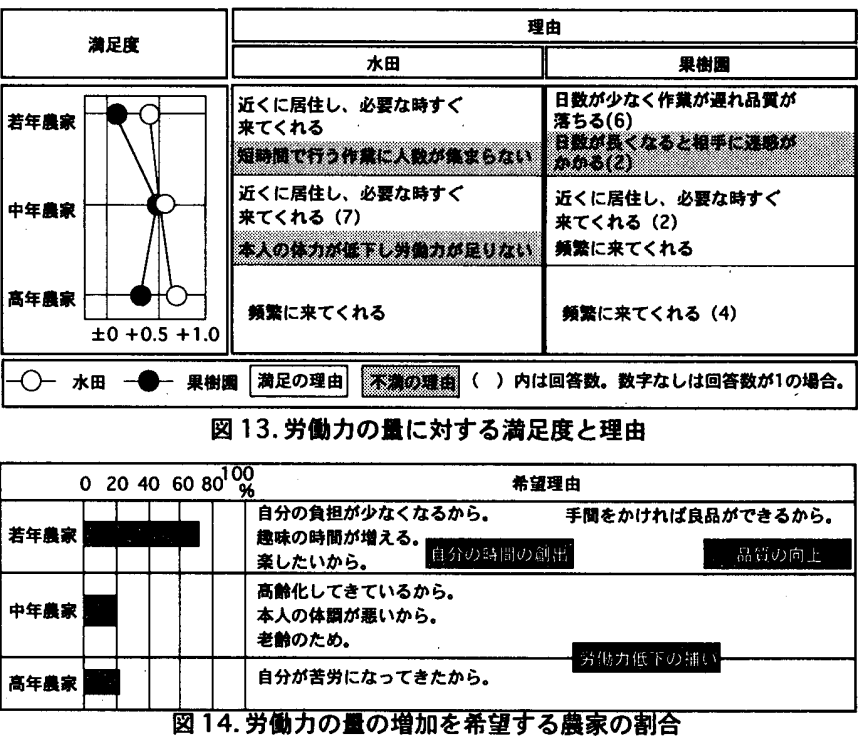

して体力低下を地域外家族が補い切れていないことが挙がった。 高年農家は水田で最も满足度が高く、果樹園も比較的高い。満足 の理由として、地域外家族が農作業を行なう頻度が高いことが挙が り、平均日数が長いことがわかる。

また、労働力の量の增加を希望する $\left.{ }^{11}\right)$ 農家の割合を図14.に示す。 若年農家では $70 \%$ 強であるのに対し、中・高年農家では $20 \%$ に留 まっており、ほぼ現状に満足していると言える。希望理由には、若 年農家では自分の時間の創出、品質の向上を望むものがあった。中・ 高年農家では体力低下の補いが主な理由である。

\section{4-2. 労倒力の質について}

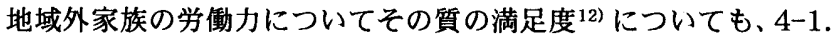
と同様の調查を行なつた。質に対する満足度と理由を図 15. に示す。 どの年䊀分類の農家も、水田より果樹園で満足度が低いが、+ 0.5 以上であり、労偅力の量に比べ満足度は高いと言える。

若年農家は、水田で最も満足度が高く、満足の理由として簡易な 農作業のみを地域外家族に行なってもらうため質には問題がないこ とが挙がった。果樹園では満足度は比較的低いと言え、満足の理由 は水田と同様であるが、不満の理由として、地域外家族の農作業を 行なうと品質が落ちることが挙がった。

中年農家は、水田では満足の理由として、地域外家族が継続的に 農作業を行うため要領を得ていることが特に多く举がった。果樹園 では最も高く、満足の理由は水田と同様である。

高年農家は、水田、果樹園とも最も満足度が低い。満足の理由と して、「来てくれるだけで助かるので質にはこだわらない」というも

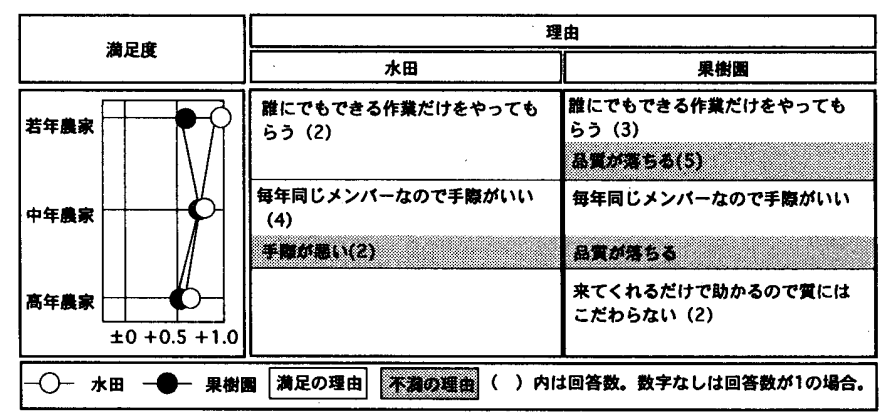

图 15.労㑬力の䓄に対する淦足度と理由 
のがあった。

\section{4-3. 小括}

以上から、農家が地域外家族の農作業をどのように評価している のか、まとめる。

若年農家では、地域外家族が農作業を行なうと品質が落ちるため、 地域外家族には簡単な作業のみを行なってもらう。全体的にみれば、 自分の時間づくりのために大半の農家が量の増加を希望しており、 そのための労衝力と評価していると言える。

中年農家では、地域外家族の労働力をタイミングよく得られ、ま た地域外家族が継続的に農作業を行なっているため要領を得ている と評価していることから、慣れ親しんだ良質の労働力と評価してい ると言える。

高年農家では、3章で明らかになった地域外家族の平均日数の長さ が、量の満足度の高さにつながっていると言える。自らの体力が低 下しており、体力の低下を補う労働力と評価していると言える。

\section{5 章 . 地域外家族の必要性}

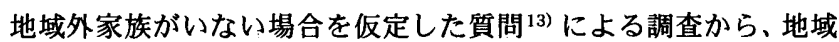
外家族の労働支援主体としての必要性と、農地の耕作を続ける上で の必要性を明らかにする。

\section{5-1. 労働支援主体としての必要性}

\section{5-1-1. 代替労働支援主体の有無}

代替労働支嗳主体の有無の割合を図 16.に示す。水田、果樹園と もに農家の年制が上がる程「有り」とする割合が低くなる。特に果 樹園では高年農家は全農家が「無し」である。

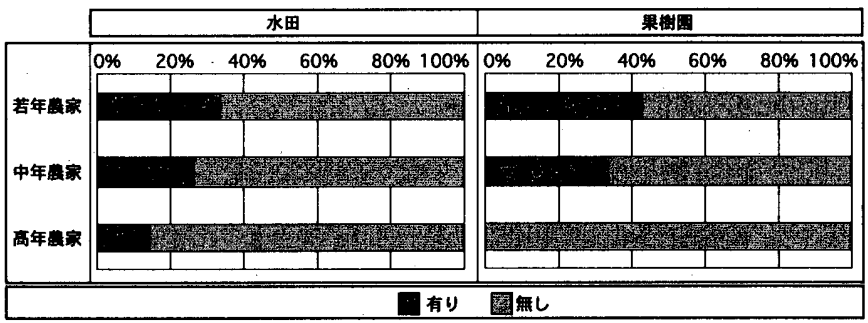

图 16.代替学做支援主体の有無

また「有り」の場合の代替労働 支援主体を図 17. に示す。若年農 家では個人的なつながりの「友 人」が多く、中年農家では「友人」 と地縁的なつながりの「近所の

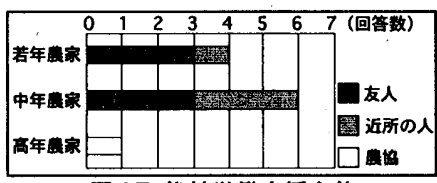

人」が半々である。高年農家は「農協」という 1 回答である。農家 の年跉が上がる程、代替労働支援主体の範囲が限られてくると言え る。

5-1-2. 困ること

代替労働支援主体が「有り」と答えた農家にその主体に農作業を

表 6. 困ること

\begin{tabular}{|c|c|c|}
\hline & 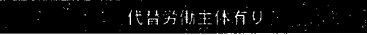 & 6EY \\
\hline 若年盘家 & 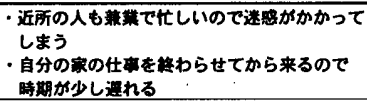 & 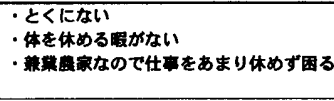 \\
\hline 中年虽家 & 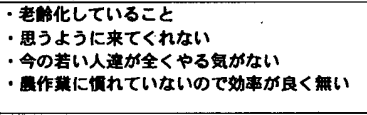 & 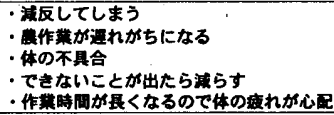 \\
\hline 高年圈家 & 回答なし & ・いつまでくかか心甜 \\
\hline
\end{tabular}

頼んだ場合に困ること、「無し」と答えた農家に自分（同居する家族 も含む）で農作業を行う場合に困ることについての回答を得た。有 無それぞれの場合について困ることを表 6.に示す。

「有り」の場合に困ることとして、若年農家では代替労働支援主体 の都合に関することが挙がった。中年農家では代替労働支援主体の 高齢化、都合に関すること、農作業に不慣れであることなどが挙 がった。

「無し」の場合に困ることとして、若年農家では自分の体を休めら れないこと、時間に余裕がなくなることが挙がった。中年農家では 農作業の遅れや、農地を減らすことも含めた体力的な不安が挙がり、 高年農家では農作業の継続が困難になるという不安が举がった。

\section{5-1-3. 労働支援主体としての必要性}

以上から、地域外家族は血縁者であるため、農家にとって使いや すい労衔支援主体であると言え、また農家の年齡が上がる程、地域 外家族の労働支援主体としての必要性が高くなると言える。

若年農家には代替労働支援主体として友人等がいるが、地域外家 族は血縁者であるため、相手の都合を気にせず必要な時に労働力が 得られる。

中年農家では、地域外家族は代替労働支援主体よりも若く、農作 業に慣れており、必要な時にその労働力が得られるため、効率良く 農作業を行なうことができ、体力の回復や耕作の継続が可能になる。

高年農家では、代替労働支援主

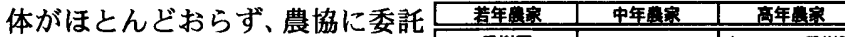
する以外にない。農家が自ら耕作 を続けていくために、地域外家族 は非常に必要性が高いと言える。

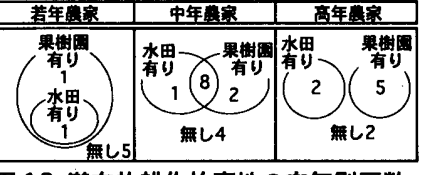
図 18.潜在的耕作放棄地の有無別戸数

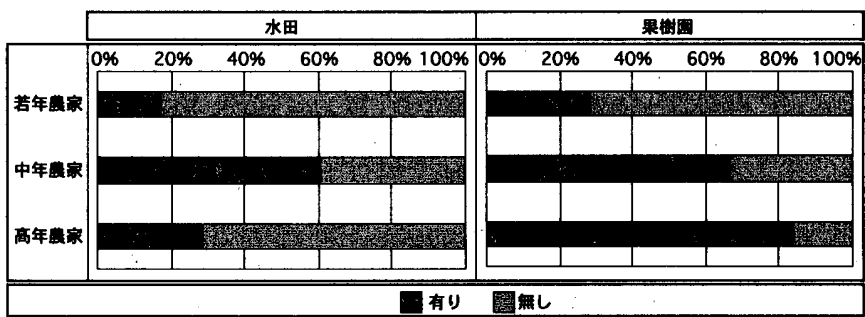

図 19.潜在的耕作放襄地の有無の割合

\section{5-2. 耕作を䌇ける上での必要性}

\section{5-2-1. 潜在的耕作放裹地の有無}

潜在的耕作放棄地の有無別の農家の戸数を図 $18 . に 、$ 割合を図 19. に示す。若年農家では、水田、果樹園とも「有り」とする割合は低 い。中年農家では、水田と果樹園の両方に「有り」とする農家が多 く、割合では水田、果樹園ともに $60 \%$ 程度と高い。高年農家では、 水田に「有り」とする農家は $30 \%$ 弱と比較的低いが、果樹園に「有 り」とする農家が $80 \%$ 強と最も高い。果樹園は農家の年柃が上がる 程「有り」とする割合が高くなる。

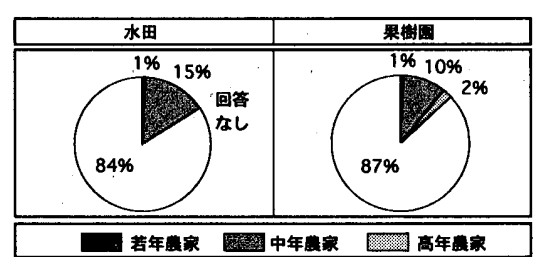

图 20. 赤田区の全農地面樌に占める 清在的耕作放襄地の割合

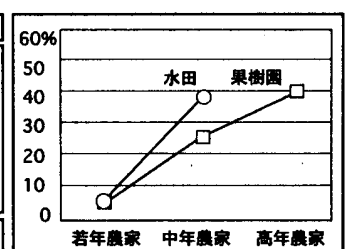

图21.潜在的耕作放交地の 割合 


\section{5-2-2. 潜在的耕作放裹地の面積}

対象地の全農地面積 ${ }^{14 ）}$ に占める潜在的耕作放棄地の面積 ${ }^{15)}$ の割 合を図 20. に示す。水田では $16 \%$ 、果樹園では $13 \%$ ありり、大半は 中年農家の農地である。

また、年秢分類ごとの農地面積に占める潜在的耕作放棄地の面積の 割合を図21.に示す。全体的に農家の年齢が上がる程、潜在的耕作放 茟地の面積が占める割合が高くなる。

\section{5-2-3.潜在的耕作放棄地の特徵}

潜在的耕作放棄地を図22.に示す。ただしその場所について若年農 家の回答はなかった。中年農家、高年農家ともに、Aエリア（ため池 周辺の谷地）と Bエリア（窪地）に集中している。その他は比較的 条件のよい斜面地に分散している。Aエリアのため池は周辺の農地を 耕作する農家による水利組合によって管理されている。Bエリアは围 場整備されていない中山間地域特有の水田である。

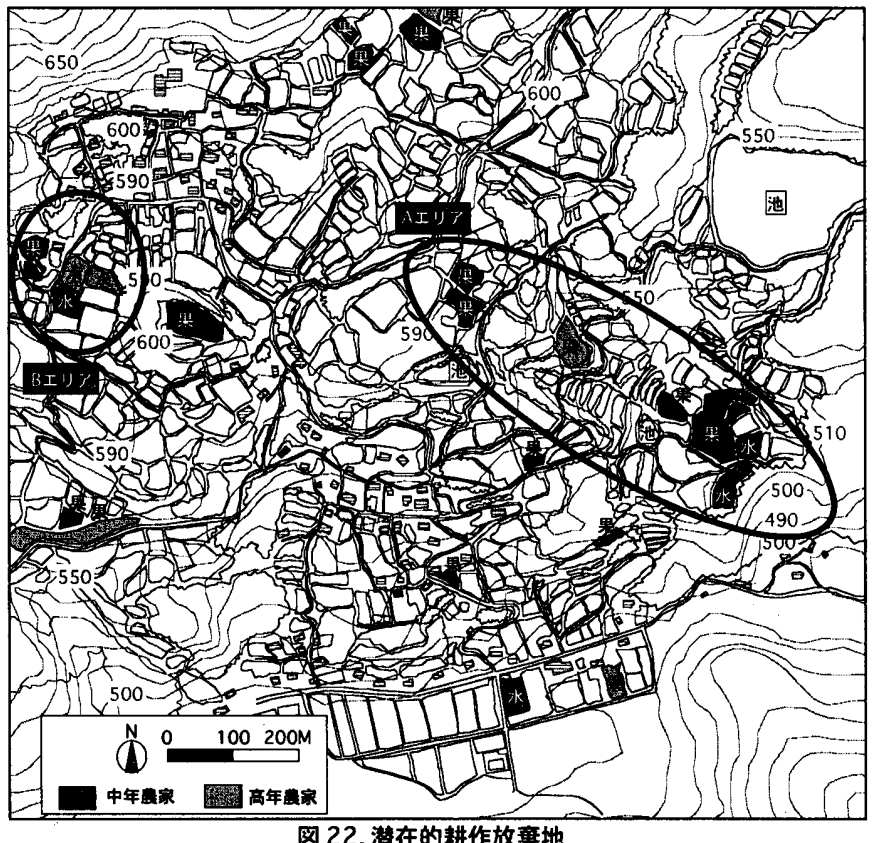

\section{5-2-4. 耕作を縝ける上での必要性}

以上をまとめると、地域外家族の労働力は水田では特に中年農家 が、果樹園では農家の年齢が上がる程、耕作を続ける上で必要性が高 いと言える。

若年農家では、潜在的耕作放棄地の面積も小さく、その場所も特定 していないことから、耕作を続ける上では地域外家族の必要性を感じ ていないと言える。

中年農家では、潜在的耕作放棄地の面積も大きく、各条件の農地に 潜在的耕作放棄地が見られた。特に、中山間地域特有の谷地や窪地に 立地する農地で耕作を続ける上で、必要性が高いと言える。

高年農家では、水田では潜在的耕作放棄地は少なく、地域外家族の 必要性は低いが、果樹園では潜在的耕作放棄地をもつ農家が多い。主 に販売目的に生産するりんごの耕作を続ける上で、農地の条件に関わ らず地域外家族の必要性があると言える。

\section{6 章 . 地域外家族による農作業の労倒力}

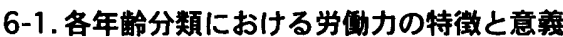

以上の結果をもとに地域外家族による農作業の労働力について図
23.に示した。各年齢分類における労働力の特徽と意義を述べる。 若年農家一人手の必要な単純作業を行いやすくする一

若年農家は、50 歳代の兼業農家であり主に妻が農作業を行なう。 体力は充分にあると考えられるが、農業以外にも活発なライフスタイ ルを持つことが伺える。

地域外家族には、技術は低いが農作業を頼みやすいことから、20 歳代で勤めを持った子や、主婦である妻の姉妹が多い。彼らはあまり 時間的余裕がないと思われ、主に水田の収穫時期などの簡易な農作業 を短時間行なう。果樹園では、地域外家族が農作業を行なうことによ る品質の低下を防ぐためもあって、農家がほとんどの農作業を時間を かけて行なっている。

つまり若年農家では、人手を必要とし短時間で終わらせる必要のあ る水田の収穫時期の農作業を、地域外家族が農家の人数の少なさを補 うことによって、効率良く行なっていると言える。

中年農家一体力低下を補い、大きな面積の耕作を可能にする一 中年農家は、60歳代の専業農家であるため人数も多く男手もあり、 大きな面積を効率良く耕作していることがわかる。しかし一方で体力 の低下が始まっている。若年農家と比較すれば、水田は自ら労働力を かけるが果樹園では地域外家族の労働力の割合が増える。

地域外家族は、主に 30 歳代の男性で勤めを持った子と、その家族 が多いが、夫が定年退職を迎え農業に関わるようになるため $50 、 60$ 歳代の夫のきょうだいも含まれ、農家 1 戸当たりの人数が多い。

彼らは継続的に農作業を行なっていることに加え、農業を職業とす る人が多いなど、農作業の経験があると考えられるため、技術が高 く、水田、果樹園とも春と秋の農繁期の農作業を効率良く行なうこと ができる。さらに現在の居住地が市内であり、对象地での農作業を行 いやすいと考えられる。

つまり中年農家では、農繁期の忙しい時期に、地域外家族が農家の 体力の低下を補うことによって、大きな面積の耕作が可能になってい ると言える。

\section{高年農家一高橉者の耕作の継続を支える一}

高年農家の多くは、70歳代の主に男性が一人で農業を行なってお り、人数は少なく、体力も低下している。農地の面積が小さく、水田 はほぼ自家用であると考えられ、自らの労働力でまかなっている。逆 に販売目的で耕作する果樹園は地域外家族の労働力によるところが大 きい。

地域外家族は、40、50 歳代の勤めを持った子とその家族や、妻の きょうだいが多いが、農家 1 戸当たりの人数は少ない。

彼らは農作業の要領を得ていると考えられ、一年間を通して多くの 農作業を行なっているが、農家の低下した労働力を少人数で補うた め、時間的余裕の違いや農作業の技術の程度に応じて、役割分担を行 なっている。地域外家族がいなければ農協に農作業を委託するしかな く、地域外家族は農家が耕作を継続していくために必要不可欠な存在 であると言える。

つまり高年農家では、面積は小規模ではあるが高棓者による耕作の 継続を、地域外家族が役割分担をしながら年間を通して支えていると 言える。

\section{6-2. 地域外家族による労值力の意義}

作業内容の範囲の拡がりと労働力に対する評価を考慮すると、農家 の年野が上がる程、地域外家族の農作業の技術が高くなっていくこと 
がわかる。また、血縁者であることの意味が強まり、労働支援主体と しての必要性が高くなっていく。これは、多くの労働力がかかる果樹 園で特に言える。このことから、長期的に地域外家族を農作業に取り 込んでいることで、地域外家族が技術を習得でき、農家の体力が低下 した時にも質の良い労働力を確保できると考えられ、結果的に耕作放 裹を防いでいると言える。特に、中山間地域特有の地形に立地する、 条件の不利な農地において地域外家族の労働力の意義が高い。

\section{6-3.まとめ}

以上から本研究では、中山間地域において、農家と地域外家族の労 働力の内容がそれぞれの年昤分類によって変化すること、相互の年齢 分類の関係において農家の低下した労働力を地域外家族が補い、農業 を支えていること、そしてそれが家族の年秢分類の移行と連動した長 期的な仕組みを持っていることが明らかになった。

このような、都市と農村をまたぐ「緩やかなイエ」という家族像 は、今後、農家の高舲化に伴い中山間地域においてさらに重要にな り、また地域外に住む個人のライフスタイルの変化に応じて多様化し ていくと考えられる。

対象地のように市街地と近接した中山間地域の農業に対して支援す る上で、農家だけでなく地域外家族も含めた家族像を捉えなおすこ と、また、そのライフステージに対する視点の必要性を示唆できる。

\section{謝辞}

調查にご協力いただいた長野市信更支所、および、アンケートにご 協力いただいた赤田区のみなさまには、この場を借りて深く御礼申し 上げます。

なお、本研究の一部は財団法人鹿島学術振興財団の助成、および、 早稲田大学特定課題研究費によるものです。記して謝意を表します。

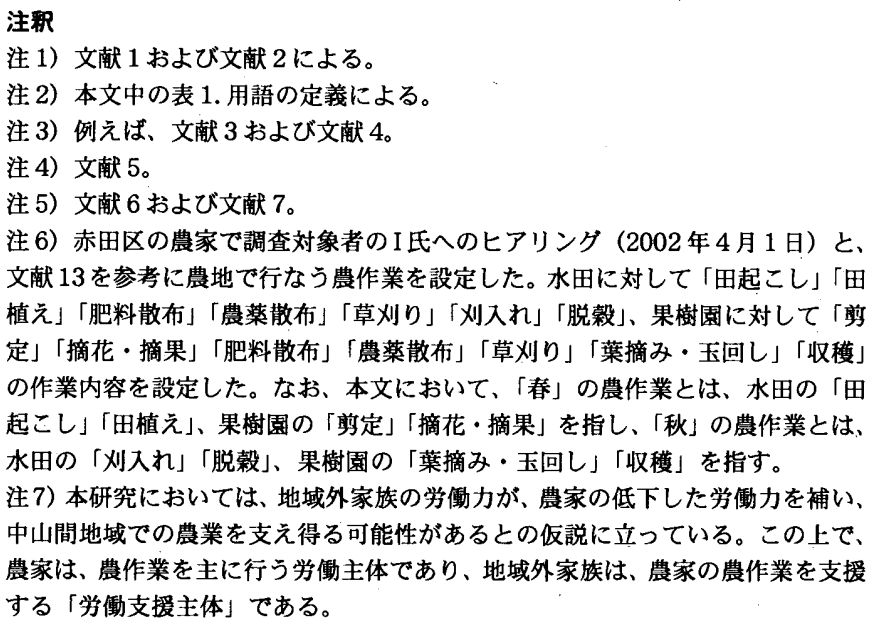
文献 13 を参考に農地で行なう農作業を設定した。水田に対して「田起こし」「田 植え」「肥料散布」「農薬散布」「草刈り」「刈入れ」「脱㲤」、果樹園に対して「剪 定」「摘花・摘果」「肥料散布」「農薬散布」「草刈り」「葉摘み・玉回し」「収穫」 の作業内容を設定した。なお、本文において、「春」の農作業とは、水田の「田 起こし」「田植え」、果樹園の「剪定」「摘花・摘果」を指し、「秋」の農作業とは、 水田の「刈入れ」「脱款」、果樹園の「葉摘み・玉回し」「収穫」を指す。 注 7) 本研究においては、地域外家族の労働力が、農家の低下した労㗢力を補い、 中山間地域での農業を支元得る可能性があるとの仮説に立っている。この上で、 農家は、農作業を主に行う労働主体であり、地域外家族は、農家の農作業を支报 する「労働支授主体」である。

注 8）51戸の有効回答を出した農家のうち、専業農家は 17 戸 (33.3\%)、兼業農 家は 34 戸 $66.7 \%)$ である。

注 9）地域外家族は戸単位ではなく、個人を単位として年齢により分類した。

注 10）アンケート調查では、手伝いの人数や日数など、手伝いの量は足りてい ると思いますか」という質問を行なった。「非常に满足」に+1.0、「どちらかと いうと満足」に+0.5、「どちらでもない」に0、「どちらかというと不满」に-0.5、 「非常に不満」に-1.0の数値を与え、平均値をとった。

注11) アンケート調査では、手伝ってくれる人たちに、今よりも多く手伝いに 来て欲しいと思いますか」という質問を行なった。

注 12）アンケート調查では、「手伝ってくれる人たちの農作業の仕事振りに満足 していますか」という質問を行なった。

注 13）代替労働主体に関しては、「もし、あなたの親族による農作業の手伝いが 無かったら、親族以外の誰かに手伝いを頼みますか。」という質問を、潜在的耕 作放萧地に関しては、「もし、あなたの親族による農作業の手伝いが無かったら、 あなたは耕作する農地を縮小しますか。という質問を行なった。

注 14）この面積は、有効回答の得られた 51 戸の農家の耕作面積の合計である。 注 15）「潜在的耕作放棄地有り」と答えた農家のうち、面積について若年農家は 全戸から、中年農家は水田について 6 回答、果樹園について 9 回答、高年農家は 果樹園について4回答が得られた。水田については回答は得られなかった。面積 を答えなかった農家の回答は無記入が 3 回答、「今はまだ分からない」とするも のが 5 回答である。

\section{文献およひ資料}

文 1) United Nation : “Demographic Yearbook -Annuaire Demographic $1952 " 1952$.

文2）国際連合経済社会局：世界人口予测デー夕 1950-2025、1990.

文3）野口邦彦、重村力: 千里地域における親族間近接居住ネットワークの形成、 日本都市計画学会学術研究論文集第 19 回 pp481-486、1984.

文4）金貞均、近江隆 : 地方中小都市及び農山村地域におけるネットワーク居住 の成立とその役割、日本建築学会計画系論文集：第528号、pp195-202、2000.2. 文 5）桂明宏：果樹園流動化論、農林統計協会、2002。

文6）斉藤雪彦ほか 4 名 : 中山間地農村における生産、居住空間の空間管理作業 に関する研究 〜茨城県大子町大沢中集落をケーススタティとして〜、日本建築 学会計画系論文集 第 527 号、pp155-162、2000.1

文7）紊藤雪彦ほか 4 名 : 中山間地域の水田作集落における生産、居住空間の空 間管理作業に関する研究 〜茨城県七会村大絽集落、真壁町入山尾集落をケース スタディとして〜、日本建築学会計画系論文集 第539号、pp163-170、2001.1. 文 8）後藤春彦、三宅諭、村上佳代、山崎義人 : 都市之農村を複眼的に眺める視 座、2001 年度日本建築学会大会 (関東) 研究想談会資料・都市と田園のグラン ドデザインー 21 世紀都市・田園論、pp5-12、2001.

文9）蓮見音彦、奥田大道: 地域社会論 住民生活と地域組織〜、有斐閣、1980. 文 10）長谷川昭彦: 農村の家族と地域社会〜その理論と課題〜、お茶の水書房、 1993.8.

文11）藤正筷、古川俊之 : ウェルカム・人口堿少社会、文藝春秋、2000.10.

文12）鈴木広、木下謙治、篠原隆弘、三浦典子：地域社会学の現在、ミネルウァ 書房、2002.7

文 13）JA 長野中央会：農業経営指標、1998。

文14）国際航業株式会社：長野市固定資産航空写真慓定図、1998

文15）株式会社ゼンリン: ゼンリン住宅地図長野市（南部版)、2002.6.

文16）国土地理院：1:25,000 地形図 稻荷山（長野 13号一 4)、2000.5. 文17) 三輪信哉:集落における建築代謝の時間構造の㚆化に関する研究〜沖縄県 与那国島における事例研究〜、日本建策学会論文報告集、第343号、pp131-141、 1984.9. 